\title{
Increased AMPA-Sensitive Quisqualate Receptor Binding and Reduced NMDA Receptor Binding in Epileptic Human Hippocampus
}

\author{
David A. Hosford, ${ }^{1}$ Barbara J. Crain, ${ }^{3,4}$ Zhen Cao, ${ }^{1}$ Douglas W. Bonhaus, ${ }^{1}$ Allan H. Friedman, ${ }^{2}$ M. M. Okazaki, ${ }^{5}$ \\ J. Victor Nadler, ${ }^{3,5}$ and James 0 . McNamara ${ }^{1,3,5}$
}

Divisions of ${ }^{1}$ Neurology and ${ }^{2}$ Neurosurgery and Departments of ${ }^{3}$ Neurobiology, ${ }^{4}$ Pathology, and ${ }^{5}$ Pharmacology, Duke University Medical Center, Durham, North Carolina 27710

Based on results from the kindling model of epilepsy, we hypothesized that enhanced binding of radioligands to the NMDA receptor and decreased binding to the $\alpha$-amino-3hydroxy-5-methyl-4-isoxazolepropionate (AMPA)-sensitive quisqualate (ASQ) receptor would be found within epileptic hippocampi of humans with complex partial epilepsy (CPE). To test these hypotheses, we used tissue that was surgically removed from patients with intractable CPE, and control tissue that was obtained at autopsy. We used autoradiographic techniques to measure ASQ receptor binding (with ${ }^{3} \mathrm{H}$-AMPA as the radioligand) and binding to 2 sites on the NMDA receptor/channel complex: the agonist recognition site (with ${ }^{3} \mathrm{H}$-glutamate) and the phencyclidine (PCP) binding site that resides within the NMDA channel [with ${ }^{3} \mathrm{H}-\mathrm{N}-\{1-[$ thienyl]cyclohexyl\}piperidine (TCP) in the presence of saturating concentrations of NMDA and glycine]. Measurements of receptor binding were corrected for pathologic alterations in neuronal density. Contrary to our expectations, ASQ receptor binding was significantly increased $(100 \% ; p<0.02)$ in the dentate gyrus stratum moleculare in patients with CPE $(n=8)$, and it was unchanged in other hippocampal regions. In nearby sections from the same specimens, binding was significantly decreased to the agonist recognition site of the NMDA receptor in the stratum oriens of area CA3 $(46 \% ; p$ $<0.05$ ) and was also decreased to the PCP site in the stratum radiatum and stratum oriens of CA3 (44\% and $74 \%$, respectively; $p<0.05$ ). The increase in ASQ receptor binding may contribute to hyperexcitability in these epileptic patients. The decreased NMDA receptor binding may reflect an injured neuronal population, a selective loss of the most NMDA-sensitive neurons, or a homeostatic down-regulation of hyperexcitability by surviving neurons. Kindling does not appear to model CPE that is associated with mesial temporal sclerosis.

\footnotetext{
Received Apr. 12, 1990; revised Sept. 4, 1990; accepted Sept. 19, 1990.

We appreciate the invaluable technical help of Linda S. Butler and Lewis C. Rigsbee and the administrative assistance of Rena Wethington. Dr. Rodney A. Radtke provided helpful information pertinent to the clinical management of the patients with epilepsy. This work was supported by NIH Grants K08-01232, NS 17771 , and NS 16064 and by grants from the Veterans Administration.

Correspondence should be addressed to Dr. David A. Hosford, Epilepsy Research Laboratory, Building 16, Room 20, Veterans Administration Medical Center, 508 Fulton Street, Durham, NC 27705.

Copyright (C) 1991 Society for Neuroscience $0270-6474 / 91 / 110428-07 \$ 03.00 / 0$
}

Excitatory amino acid (EAA) receptors may play a role in many neurologic diseases (Greenamyre et al., 1985; Meldrum, 1985; Fagg et al., 1986; Turnbull, 1987), including epilepsy. Increased involvement of the NMDA subtype of EAA receptors in excitatory synaptic function (Mody and Heinemann, 1987) and increased sensitivity of NMDA receptors (Morrisett et al., 1989) may underlic the kindling model of complex partial seizures. Biochemical studies of NMDA receptors in the hippocampus of kindled rats have shown increased binding to the phencyclidine (PCP) sites (Yeh et al., 1989) that likely reside within the NMDA-receptor-gated ion channel (Reynolds et al., 1987; Bonhaus et al., 1988; Huettner and Bean, 1988; Kloog et al., 1988; Hosford et al., 1990). Similar increases were found in binding to the glycine and competitive antagonist $3-[+]-2-\{$ carboxypiperazin-yl $\}$ propyl-1-phosphonic acid (CPP) recognition sites (Yeh et al., 1989). In contrast, autoradiographic studies showed unchanged or even reduced binding to the agonist recognition site of the NMDA receptor (Okazaki et al., 1989). Transiently decreased binding to the $\alpha$-amino-3-hydroxy-5-methyl-4-isoxazolepropionate- (AMPA) sensitive quisqualate (ASQ) receptor subtype of EAA receptor has also been demonstrated in the kindling model (Okazaki et al., 1990).

Assuming that the kindling model reflects physiological changes relevant to complex partial epilepsy (CPE) in humans, we hypothesized that NMDA receptor binding would be increased in human CPE, whereas ASQ receptor binding would be decreased. We therefore studied hippocampal tissue that was surgically removed from patients with intractable CPE. Control hippocampal tissue was obtained at autopsy. We used a receptor autoradiographic technique to examine binding to ASQ receptors (Monaghan et al., 1984) and to 2 sites on the NMDA receptor: the agonist recognition site (Okazaki et al., 1989) and the PCP binding site (Bonhaus et al., 1988; Hosford et al., 1988, 1990; Yeh et al., 1989). Because measurements were made in pathologically altered epileptic tissue, we corrected measurements of receptor binding for differences in neuronal density.

Portions of this work have been presented in abstract form (Hosford et al., 1989a,b).

\section{Materials and Methods}

Brain tissue. Eight patients with medically intractable complex partial epilepsy underwent resection of the anterior $5-6 \mathrm{~cm}$ of one temporal lobe $(n=6$ males and 2 females; ages, $14-40 \mathrm{yr}$; mean age $=23 \pm 8$ yr). A $5-\mathrm{mm}$-thick section of the resected tissue containing easily recognized dentate gyrus was immediately covered with Tissue-Tek OCT Compound and frozen with Freon. The remaining tissue was embedded 
in paraffin and processed for diagnostic neuropathologic analysis. Tissue was stored at $-70^{\circ} \mathrm{C}$ until cutting. The anterior temporal lobe was removed at autopsy (postmortem intervals $=3,4,5$, and $10 \mathrm{hr}$ ) from 4 patients who died from nonneurologic causes ( $n=4$ males; ages, 35$66 \mathrm{yr}$; mean age $=50 \pm 12 \mathrm{yr}$ ). This control tissue was frozen and stored exactly as described above. Epileptic and control tissue was sequentially brought to $-18^{\circ} \mathrm{C}$, cut into $10-\mu \mathrm{m}$-thick sections with a cryostat, thaw mounted onto acid-washed gelatin-coated glass microscope slides, and stored at $70^{\circ} \mathrm{C}$ until necded. Prior to preincubation, slides were placed at $-18^{\circ} \mathrm{C}$ for $10 \mathrm{~min}$, and then at $20^{\circ} \mathrm{C}$ for another $10 \mathrm{~min}$. The sections were subjected to one of the receptor binding protocols described below.

${ }^{3} \mathrm{H}$ - $\alpha$-amino-3-hydroxy-5-methyl-4-isoxazolepropionate (AMPA) binding protocol. Sections from epileptic and control brains were preincubated twice for $15 \mathrm{~min}$ each at $4^{\circ} \mathrm{C}$ in $50 \mathrm{~mm}$ Tris-acetate buffer $(\mathrm{pH}$, 7.2) to promote removal of endogenous amino acids (Okazaki et al., 1990). A 20 -min incubation in the same buffer was performed at $4^{\circ} \mathrm{C}$ in the presence of $75 \mathrm{nM}{ }^{3} \mathrm{H}$-AMPA ( $28 \mathrm{Ci} / \mathrm{mmol}$; Amersham). Nonspecific binding was defined as the amount of ${ }^{3} \mathrm{H}-\mathrm{AMPA}$ binding obtained in the presence of $50 \mu \mathrm{M}$ unlabeled AMPA. Specific binding was calculated as the difference in binding in the presence and absence of unlabeled AMPA. After incubation, sections were rapidly dipped twice into $50 \mathrm{mM}$ Tris-acetate buffer, once into distilled $\mathrm{H}_{2} \mathrm{O}$, and then once into $2.5 \%$ glutaraldchyde in acctonc. Sections were quickly air dried $(<30 \mathrm{sec})$ and were processed for autoradiography as described below.

$N M D A$-displaceable ${ }^{3} \mathrm{H}$-glutamate binding protocol. Sections from epileptic and control brains were preincubated twice for $15 \mathrm{~min}$ each at $4^{\circ} \mathrm{C}$ in $50 \mathrm{~mm}$ Tris-acetate buffer (pH, 7.2; Okazaki et al., 1989). A 20min incubation in the same buffer was performed at $4^{\circ} \mathrm{C}$ in the presence of $75 \mathrm{nM}^{3} \mathrm{H}$-glutamate $(52 \mathrm{Ci} / \mathrm{mmol}$; Amersham), $20 \mu \mathrm{M}$ AMPA (Tocris Neuramin, Essex, England), and $5 \mu \mathrm{M}$ kainic acid (Sigma). Nonspecific binding was defined as the amount of ${ }^{3} \mathrm{H}$-glutamate binding in the presence of $250 \mu \mathrm{M}$ NMDA. Specific binding was calculated as the difference in binding in the presence and absence of NMDA. After incubation, sections were washed and dried as described in the protocol for ${ }^{3} \mathrm{H}$-AMPA binding. Processing for autoradiography was performed as described below.

${ }^{3} H$-N-\{1-[thienyl]cyclohexyl $\}$ piperidine (TCP) binding protocol. Sections from epileptic and control patients were treated as described previously (Bonhaus et al., 1988; Hosford et al., 1988, 1990). Preincubation was carried out for $2 \mathrm{hr}$ at $4^{\circ} \mathrm{C}$ in $50 \mathrm{~mm}$ Tris-acetate (pH, 7.2; Sigma) containing $0.1 \%$ formalin and $1 \mathrm{~mm}$ EDTA (Sigma), followed by 15 min at $30^{\circ} \mathrm{C}$ in identical preincubation buffer. Sections were then washed for $5 \mathrm{~min}$ at $20^{\circ} \mathrm{C}$ in $5 \mathrm{mM}$ Tris-acetate $(\mathrm{pH}, 7.2)$ containing $100 \mu \mathrm{M}$ EDTA. Incubation was performed for $5 \mathrm{~min}$ at $20^{\circ} \mathrm{C}$ in the same buffer, with the following additions: $2 \mathrm{nM}{ }^{3} \mathrm{H}-\mathrm{TCP}(42-60 \mathrm{Ci} / \mathrm{mmol}$; Amersham), $100 \mu \mathrm{M}$ NMDA (Tocris Neuramin, Essex, England), and $10 \mu \mathrm{M}$ glycine (Sigma). Nonspecific binding was measured by the inclusion of $10 \mu \mathrm{M}$ phencyclidine (PCP; Sigma). Specific binding was calculated as the difference in binding in the presence and absence of PCP. Incubation was terminated by a quick dip in distilled $\mathrm{H}_{2} \mathrm{O}$, followed by 25 -min washes in $5 \mathrm{~mm}$ Tris-acetate $(\mathrm{pH}, 7.2)$ at $4^{\circ} \mathrm{C}$. Sections werc then rapidly dipped into distilled $\mathrm{H}_{2} \mathrm{O}$ and then into $2.5 \%$ glutaraldehyde in acetone. They were quickly air dried and processed for autoradiography as described below.

Exposure, development, and measurement of autoradiograms. Slides were apposed alongside tritium-labeled brain-paste standards to LKB ${ }^{3} \mathrm{H}$-Ultrofilm. Exposure occurred at $-70^{\circ} \mathrm{C}$ for $4-6$ weeks before development with Kodak D-19 and rapid fixer. A computer-based RAS/ R1000 image analysis system (Loats, Inc.) was used to digitize the autoradiograms for analysis of regional optical densities. The identical sections used to generate the autoradiograms were then stained with cresyl violet, digitized with the image analysis system, and used for redirected regional sampling to ensure proper identification and unbiased analysis of the chosen hippocampal regions.

The full widths of the following dendritic regions were analyzed (scc Fig. 1): a $0.09-\mathrm{mm}^{2}$ portion of the suprapyramidal dentate gyrus stratum moleculare (DSM; designated superior DSM; mean width, $184 \pm 9 \mu \mathrm{m}$ in sections from control brains and $187 \pm 10 \mu \mathrm{m}$ in sections from epileptic brains); a $0.10-\mathrm{mm}^{2}$ portion of the dentate gyrus stratum moleculare that was $180^{\circ}$ around the dentate granule cell (DCG) layer and hence was opposite the superior dentate stratum moleculare (designated inferior DSM; mean width, $239 \pm 22 \mu \mathrm{m}$ in sections from control brains and $233 \pm 17 \mu \mathrm{m}$ in sections from epileptic brains); $0.11-\mathrm{mm}^{2}$ portions of the stratum radiatum (mean width, $303 \pm 41 \mu \mathrm{m}$ in sections from control brains and $258 \pm 15 \mu \mathrm{m}$ in sections from epileptic brains) and stratum oriens (mean width, $308 \pm 42 \mu \mathrm{m}$ in sections from control brains and $282 \pm 21 \mu \mathrm{m}$ in sections from epileptic brains) of area CA3; and $0.10-\mathrm{mm}^{2}$ portions of the stratum radiatum (mean width, $270 \pm$ $16 \mu \mathrm{m}$ in sections from control brains and $253 \pm 16 \mu \mathrm{m}$ in sections from epileptic brains) and stratum oriens (mean width, $201 \pm 14 \mu \mathrm{m}$ in sections from control brains and $240 \pm 16 \mu \mathrm{m}$ in sections from epileptic brains) of area CAl. Specimens with mesial temporal sclerosis contained atrophic segments devoid of neurons, but the regions analyzed were deliberately chosen to represent segments with many intact neurons. Optical density measurements of the autoradiograms generated by the tritium standards allowed conversion of regional optical density measurements into molar units.

Determination of regional neuronal counts. To correct for pathologic alterations in the tissue, we counted the neurons that would likely contribute dendrites to the dendritic zones measured. Golgi analyses of the hippocampus [Lorente de Nó, 1934; Ramón y Cajal, 1968 (translated)] demonstrated that the apical dendrites of pyramidal and granule cells radiate perpendicular to the cell body layer and parallel to each other. We therefore counted neurons in that portion of the cell body layer directly beneath or above the dendritic zones in which receptor binding was measured. These neuronal counts were used to calculate a value of receptor binding per neuron. It is possible that the neuronal counts used for this analysis did not fully account for all neurons that contribute processes to the relevant dendritic zones. However, the magnitude of this error was probably equal in epileptic and control tissue, because the widths of the cell body layers and dendritic zones chosen for the analysis did not significantly differ in the 2 sets of tissue. For that reason, these neuronal counts allow meaningful comparisons between equivalent regions in the 2 sets of specimens. However, the values obtained by our procedure cannot be used to infer the overall extent of cell loss in these hippocampi and are not comparable to cell counts that were performed for this purpose (Mouritzen Dam, 1982; Babb et al., 1984 Mani et al., 1986).

Neurons were counted under $137 \times$ magnification in $350 \times 250-\mu \mathrm{m}$ areas at each site within the dentate granule cell layer and in $350 \times$ $500-\mu \mathrm{m}$ areas at each site within the CAl and CA3 pyramidal cell layers. Cells were counted as neurons only if they met 3 criteria: (1) the presence of a discrete cell body $\geq 10 \mu \mathrm{m}$ in diameter, (2) the presence of a discrete nucleus and cytoplasm, and (3) an approximately circular profile for dentate granule cells and a pyramidal profile for pyramidal cells. In pilot studies, similar regional neuronal counts were determined by both D.A.H and B.J.C. (a neuropathologist). Pilot experiments disclosed identical mean neuronal counts regardless of whether the section counted was the first, middle, or last taken from a particular brain specimen; the first section from each brain specimen was used for all subsequent neuronal counting. This section was one of those used to measure receptor binding, as well.

Formulas to correct the neuronal counts for possible sampling errors (Konigsmark, 1969) were not used, because the size of neurons within equivalent cell body layers was not significantly different comparing sections from epileptic and control brains (data not shown). For that reason, use of the formulas would change neuronal counts in both epileptic and control specimens by the same degree. Therefore, use of these formulas would alter neither the magnitude nor the significance of any difference in receptor binding values of equivalent regions of epileptic and control sections.

The cell count that best represented the number of neurons contributing to the dendritic zone analyzed was calculated as follows for each site: First, the 3 values obtained after counting at each site were averaged to obtain a mean cell count. The total cell count adjacent to the dendritic zones analyzed was then computed by multiplying the mean cell counts by the following factor:

(length of dendritic zone analyzed) (width of cell body layer) (area of cell body layer in which mean cell counts were obtained)

The receptor binding measurements were divided by this corrected value of total cell counts. The resulting value has units of attomoles of binding per cell ( 1 attomole $\left.=10^{-18} \mathrm{~mol}\right)$. This corrected value removed any bias from pathologic decreases in neuronal density.

Statistical analysis. The following analysis was performed separately for each of the 3 receptor binding sites measured. A 2-way analysis of variance (ANOVA) was performed across regions (columns) and between epileptic and control data (rows) to assess whether any differences in receptor binding were significant at the 0.05 level. Whenever a sig- 
Table 1. Cell counts in cell body layers adjacent to dendritic zones analyzed $^{a}$

\begin{tabular}{lcrll} 
& \multicolumn{2}{c}{} & \multicolumn{2}{l}{ Pyramidal cells } \\
\cline { 2 - 3 } \cline { 5 - 6 } & \multicolumn{2}{c}{ DGC layer } & Area & \multicolumn{1}{c}{ Area } \\
& Superior & Inferior & CA3 & CA1 \\
\hline Control $(n=4)$ & $123 \pm 20$ & $113 \pm 6$ & $142 \pm 30$ & $78 \pm 5$ \\
Epilepsy $(n=8)$ & $56 \pm 9$ & $53 \pm 6$ & $132 \pm 18$ & $56 \pm 5$
\end{tabular}

${ }^{a}$ Neurons were counted in the cell body layers adjacent to the dendritic zones analyzed. Values are means \pm SEM for $n=$ number of cases. The appropriate value for a particular region was used as the denominator for expression of receptor binding (Table 2)

${ }^{b}$ See Materials and Methods and Figure 1 for details of superior and inferior portions of the DGC layer.

nificant difference was found by 2-way ANOVA, a post hoc least-significant difference (LSD) test was used to define the particular region(s) causing the significant difference $(p<0.05)$ in receptor binding.

\section{Results}

\section{Loss of hippocampal neurons}

When compared to control material, regions chosen in the sections from epileptic brains were consistently observed to have lost a considerable number of neurons from the DGC layer and a smaller number from the CA1 pyramidal cell layer (Table 1). The loss of granule cells (54\%) was similar to that obtained in other studies of human mesial temporal sclerosis (Mouritzen Dam, 1982; Babb et al., 1984; de Lanerolle et al., 1989; Masukawa and O'Connor, 1989). The less dramatic loss of CA1 pyramidal cells (29\%) is explained by the purposeful selection (for analysis and for counting) of segments of CA1 that were not completely devoid of neurons. The overall magnitude of CA1 neuronal loss in these specimens was considerably greater than $29 \%$.

\section{AMPA-sensitive quisqualate $(A S Q)$ receptor binding}

The regional pattern of ASQ receptor binding in both epileptic and control human hippocampi (Fig. 1) was similar to that obtained in the rat hippocampus (Monaghan et al., 1984; Okazaki et al., 1990) and in the postmortem human hippocampus (Jansen et al., 1989). The ASQ receptor binding within human hippocampi with mesial sclerosis was significantly elevated in the DSM (91-108\% increase; $p<0.02)$ compared to controls (Table 2). There was a trend toward increased ASQ receptor binding (13\%) within the DSM even when the measurements were not corrected for pathologic alterations of neuronal density.

\section{NMDA receptor binding}

The regional distribution of NMDA-sensitive ${ }^{3} \mathrm{H}$-glutamate binding (Fig. 2) was similar to that obtained in the rat hippocampus (Monaghan and Cotman, 1985; Maragos et al., 1988) and in the postmortem human hippocampus (Jansen et al., 1989). NMDA receptor binding was significantly reduced in the stratum radiatum of hippocampal area CA3 in sections from epileptic patients $(46 \% ; p<0.02$; Table 2$)$. Significant reductions in area CA3 $(29-42 \% ; p<0.02)$ wcrc apparent even when measurements were not corrected for the minor alterations in neuronal density observed in this region.

The binding of ${ }^{3} \mathrm{H}-\mathrm{TCP}$ to the PCP binding site within the NMDA-receptor-gated ion channel gave results that were qualitatively similar to those obtained for the agonist recognition site. The regional distribution of ${ }^{3} \mathrm{H}-\mathrm{TCP}$ binding resembled that reported in the rat hippocampus (Hosford et al., 1988, 1990; Maragos et al., 1988) and in the postmortem human hippocampus (Jansen et al., 1989; McGonigle et al., 1989). Epileptic specimens had significantly less $(44-74 \% ; p<0.05){ }^{3} \mathrm{H}$-TCP binding within the stratum radiatum and stratum oriens of hippocampal area CA3 (Table 2). Decreased ${ }^{3} \mathrm{H}$-TCP binding within CA3 (26\%) was apparent even when measurements were not corrected for alterations in neuronal density. The regions showing decreased ${ }^{3} \mathrm{H}$-TCP binding to the NMDA-receptor-gated ion channcl werc identical to the regions showing decreased ${ }^{3} \mathrm{H}$ glutamate binding to the NMDA receptor agonist recognition site.

\section{Discussion}

Two significant findings emerge from our data: First, there was a significant increase in ASQ receptor binding in the dentate gyrus of epileptic hippocampi with mesial sclerosis. Second, binding to the NMDA receptor agonist recognition site and PCP binding site was significantly reduced in hippocampal area CA3 of epileptic patients with mesial temporal sclerosis. These findings differ from those obtained in the kindling model.

\section{Possible confounding factors within the study}

The central issue is whether the receptor binding measurements are free from distortion imposed by pathologic loss of neurons in the cpilcptic hippocampi. Because Golgi analyses show that the cell body layers contribute processes to the adjacent dendritic

Table 2. EAA receptor binding in the control and epileptic human hippocampus

\begin{tabular}{|c|c|c|c|c|c|c|c|}
\hline & & & & Area CA3 & & Area CA1 & \\
\hline & & DSM & & Stratum & Stratum & Stratum & Stratum \\
\hline & & Superior & Inferior & oriens & radiatum & oriens & radiatum \\
\hline${ }^{3} \mathrm{H}$-AMPA & Control & $179 \pm 39$ & $161 \pm 25$ & $381 \pm 30$ & $299 \pm 29$ & $551 \pm 144$ & $427 \pm 91$ \\
\hline & Epilepsy & $386 \pm 81^{*}$ & $330 \pm 78^{*}$ & $211 \pm 48$ & $298 \pm 45$ & $581 \pm 145$ & $408 \pm 94$ \\
\hline${ }^{3} \mathrm{H}$-Glutamine & Control & $78 \pm 20$ & $85 \pm 21$ & $122 \pm 8$ & $139 \pm 16$ & $233 \pm 83$ & $209 \pm 49$ \\
\hline & Epilepsy & $165 \pm 60$ & $160 \pm 60$ & $66 \pm 24^{*}$ & $117 \pm 37$ & $187 \pm 57$ & $185 \pm 72$ \\
\hline${ }^{3} \mathrm{H}-\mathrm{TCP}$ & Control & $42 \pm 20$ & $51 \pm 25$ & $57 \pm 26$ & $50 \pm 23$ & $78 \pm 35$ & $123 \pm 36$ \\
\hline & Epilepsy & $29 \pm 13$ & $41 \pm 14$ & $15 \pm 6^{*}$ & $28 \pm 10^{*}$ & $39 \pm 18$ & $72 \pm 30$ \\
\hline
\end{tabular}

\footnotetext{
${ }^{a}$ Values are means \pm SEM for 8 epileptic brains and 4 control brains, given as (attomoles of binding)/neuron, where 1 attomole $=10^{-18}$ mol.

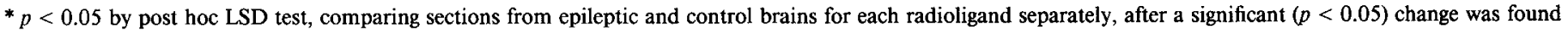
by 2-way ANOVA.
} 


\section{QUISQUALATE RECEPTOR BINDING}

NISSL
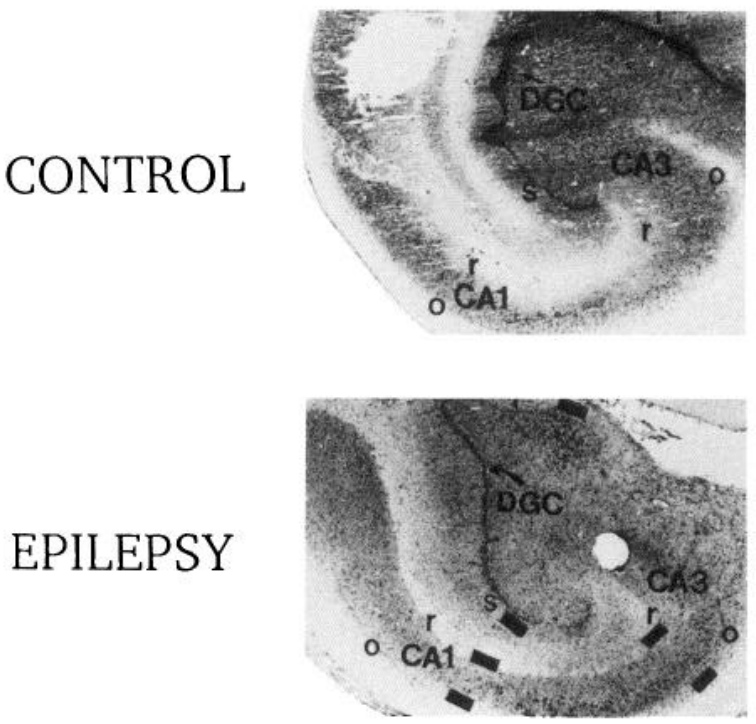

TOTAL
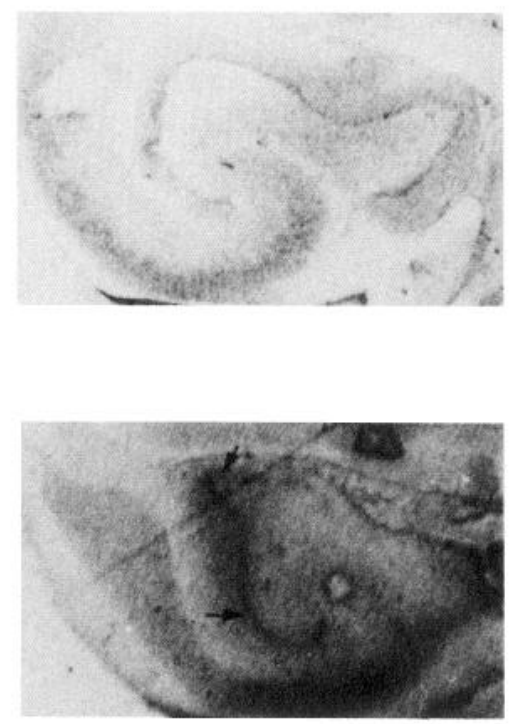

NONSPECIFIC
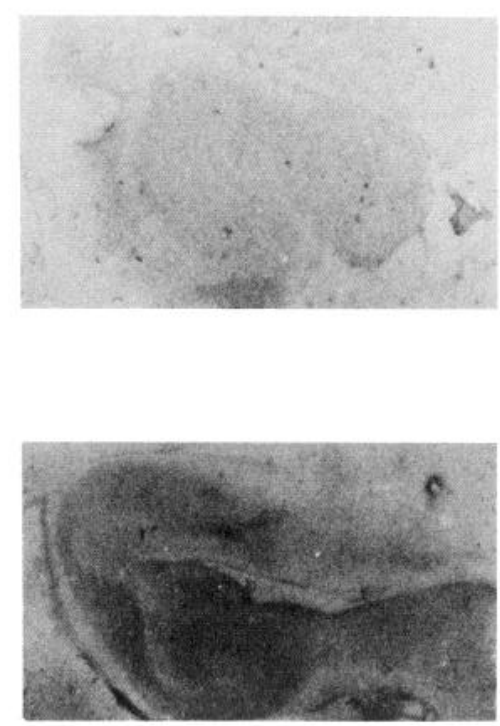

Figure 1. ${ }^{3} \mathrm{H}$-AMPA binding in control and epileptic human hippocampus. Shown in the top row, from left to right, are a Nissl-stained section from a control hippocampus, an autoradiogram of the same control section incubated with ${ }^{3} \mathrm{H}$-AMPA (total binding), and an autoradiogram of an adjacent section from the same control specimen, incubated with both ${ }^{3} \mathrm{H}-\mathrm{AMPA}$ and unlabeled AMPA (nonspecific binding). The regions analyzed include superior $(s)$ and inferior $(i)$ portions of the DSM, and the stratum radiatum $(r)$ and stratum oriens $(o)$ of hippocampal areas $C A 3$ and $C A 1$. The $D G C$ is also indicated for orientation. The black rectangles indicate the areas analyzed in each dendritic zone; cell counts were obtained in the cell body layers adjacent to these areas. The second row contains sections from an epileptic hippocampus with mesial temporal sclerosis, incubated with the same solutions and stained in the same manner as described above. Mesial temporal sclerosis (Ammon's horn sclerosis) is evident from the loss of neurons in the DGC and area CA1 (see Table 1). The black arrow in the epileptic stratum moleculare marks significantly increased ASQ receptor binding (see Table 2).

zones, we determined the number of neurons in an area directly above or beneath the dendritic zones measured and used this value as the denominator to correct all measurements of receptor binding. Within the portions of the hippocampi analyzed, there were no significant differences between sections from epileptic and control patients in the diameters of neuronal somata or in the widths of the somatic layers. The neuronal counts used to correct the measurements of receptor binding thus permit a valid comparison of equivalent hippocampal regions in the 2 sets of specimens.

Tissue shrinkage is another potential artifact that could alter the measurements of receptor binding. An additional finding demonstrates that shrinkage did not affect our measurements. There was no significant difference in the widths of dendritic regions chosen for analysis in sections from epileptic and control brains, proving the absence of tissue shrinkage within the portions of the dendritic zones analyzed. Thus, our method of correction accounted for neuronal loss and was unaffected by tissue shrinkage, permitting a meaningful comparison between regions from epileptic and control brains.

The age difference between the epileptic and control subjects is another factor of our study. Mani et al. (1986) found a $15 \%$ decrease in pyramidal cell density in hippocampi from nonepileptic patients between the ages of $25 \mathrm{yr}$ (the mean age of the epileptic patients) and $52 \mathrm{yr}$ (the mean age of the control patients). However, our calculation of receptor binding per neuron corrects for any age-dependent neuronal loss. Another possible concern is an age-dependent reduction in NMDA receptor binding. Even if NMDA receptor binding declines with age, as suggested by studies from rodents (Bonhaus et al., 1990), this factor would not explain the significantly greater NMDA receptor binding in the older control group compared to the younger, epileptic group. Finally, a gradual decline of ASQ binding with age would have explained a global decrease in ASQ binding in the older control group compared to the younger epileptic group. However, the decreased ASQ binding in the older control group was selective for the DSM and was not significantly changed from the younger epileptic group in other regions. Thus, for aging to explain the decreased ASQ binding in control material, its effect would have to be confined to DGCs. Although this seems unlikely, a final judgment awaits the study of nonepileptic material from younger patients.

Control and epileptic patients also differed in the method of tissue procurement (surgical vs. postmortem). It is conceivable that the prolonged postmortem interval might itself have modified ligand binding. However, analyses of the rat brain demonstrated remarkable stability of NMDA receptor binding, despite prolonged intervals between death and freezing of the tissue 


\section{NMDA RECEPTOR BINDING}

NISSL

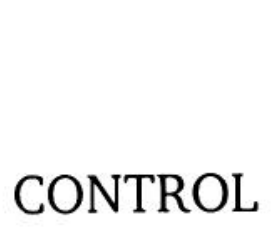

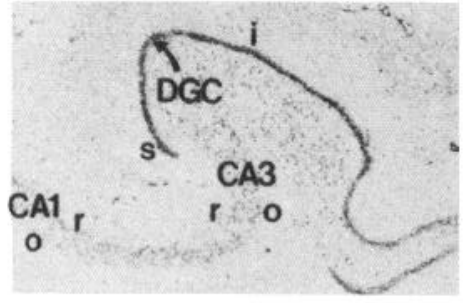

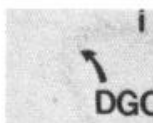

EPILEPSY

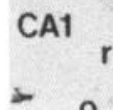

TOTAL
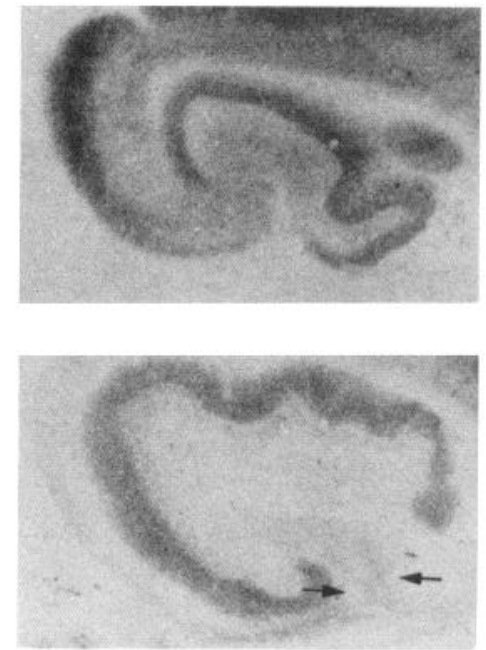

NONSPECIFIC
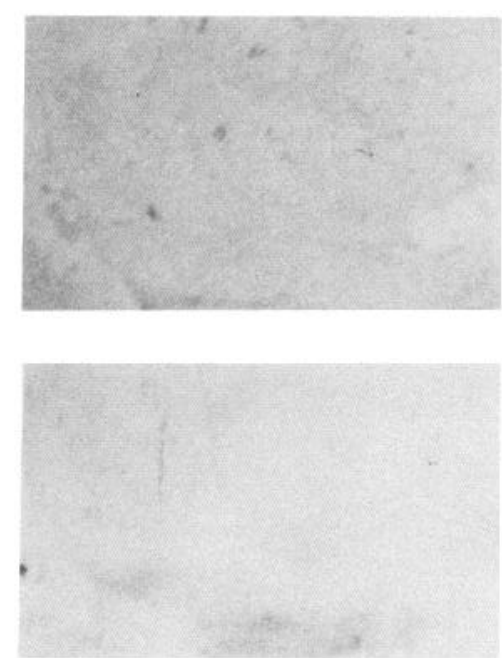

Figure 2. NMDA-displaceable ${ }^{3} \mathrm{H}$-glutamate binding in control and epileptic human hippocampus. Shown in the top row, from left to right, are a Nissl-stained section from a control hippocampus, labeled as in Fig. 1, an autoradiogram of the same control section incubated with ${ }^{3} \mathrm{H}$-glutamate (total binding), and an autoradiogram of an adjacent control section incubated with ${ }^{3} \mathrm{H}$-glutamate and NMDA (nonspecific binding). In the second row are sections from an epileptic hippocampus with mesial temporal sclerosis, incubated and stained as indicated. Mesial temporal sclerosis (Ammon's horn sclerosis) is evident from the loss of neurons in the DGC and area CA1 (Table 1). Black arrows in the stratum radiatum and stratum oriens of CA3 of epileptic hippocampus mark significantly increased NMDA receptor binding (Table 2).

(Geddes et al., 1986). Furthermore, in preliminary experiments, we demonstrated that the addition of NMDA and glycine to the incubation buffer enhanced basal ${ }^{3} \mathrm{H}-\mathrm{TCP}$ binding to the NMDAreceptor-gated ion channel by $100 \%$ in tissue obtained from both control and epileptic patients. This similarity in the degree of NMDA and glycine stimulation of ${ }^{3} \mathrm{H}-\mathrm{TCP}$ binding suggests that our postmortem intervals did not alter the integrity of the NMDA receptor.

Epileptic patients differed from control patients in their anticonvulsant treatment and in their surgical anesthesia. These potentially confounding factors would be expected to produce similar effects in all regions. Therefore, the regional selectivity of the receptor binding changes reduces the likelihood that administration of anticonvulsants or anesthesia can explain our findings.

Finally, this comparison assumes that ASQ and NMDA receptors are expressed predominantly by neurons in both control and epileptic brains. However, astrocytes in culture can express ASQ receptors (Glaum et al., 1990). The possible contribution of astrocytic receptors to our results requires further investigation.

\section{Possible significance of increased ASQ receptor binding}

Several cellular and/or molecular changes associated with epilepsy could account for the selective increase in ASQ receptor binding in the DSM. Increased binding could reflect a selective sparing of neurons that express a greater than average share of ASQ receptors. However, though electrophysiologic evidence suggests that NMDA and quisqualate/kainate receptors are lo- calized at the same synapses (Bekkers et al., 1989), we found no selective increase in NMDA receptor binding in parallel with the increased ASQ binding. Taken together with the lack of evidence for populations of granule cells that are heterogeneous for NMDA and ASQ receptors, these data suggest that the selective increase in ASQ receptor binding probably cannot be explained by selective sparing.

The increased ASQ receptor binding could reflect either an increased number of functional receptors or an increased affinity for the ligand. The precise reason is unknown, because only a single concentration of radioligand was used. In either case, the increased binding could be associated with an increased sensitivity to synaptically released transmitter. These measured changes in ASQ receptor binding are in a dendritic zone that normally receives fibers mainly from the entorhinal cortex. However, aberrant sprouting of mossy fibers (DGC axons) into this region has been observed in patients with CPE (Babb et al., 1989; Represa et al., 1989; Sutula et al., 1989; Houser et al., 1990 ) and in animal models of epilepsy (Tauck and Nadler, 1985; Sutula et al., 1988). Both of these pathways are presumed to operate through the action of glutamate on quisqualate receptors (Cotman and Monaghan, 1986). The increased excitatory input that may result from mossy fiber sprouting, together with the increased ASQ receptor binding that we measured, could dramatically heighten the excitatory effects of neurotransmitter released after perforant path activation in these epileptic hippocampi. Because the granule cells normally act to dampen high-frequency firing through hippocampal pathways (Collins et al., 1983), these modifications within epileptic hippocampi 
may participate in the initiation and/or propagation of seizures in these patients.

It should be noted that our findings are relevant mainly to the preserved "islands" of tissue in an otherwise sclerotic temporal lobe, because hippocampal regions with few neurons were excluded from the analysis. Physiologic measurements within the sclerotic temporal lobe would be required to determine whether the increased ASQ binding in regions still heavily populated with neurons is functionally significant. Indirect evidence that these data may have functional significance is provided by the improved seizure control after temporal lobectomy. It would also bc uscful to determinc whcther ASQ reccptor antagonists are effective anticonvulsants in this group of patients.

\section{Possible significance of decreased NMDA receptor/channel binding}

NMDA receptors normally play a role in high-frequency but not low-frequency neurotransmission (Fagg et al., 1986). They are especially important in the genesis of seizures (Croucher et al., 1982) and of kindling (McNamara et al., 1988). Thus, the decreased NMDA receptor binding in area CA3 of hippocampi with mesial temporal sclerosis may represent a homeostatic attempt by surviving neurons to reduce their susceptibility to seizures that depend on the activation of NMDA receptors. A less likely explanation is that mesial temporal sclerosis is accompanied by selective loss of the most NMDA-sensitive neurons, perhaps the neurotoxic result of excessive firing of afferents using ncurotransmitters that activate NMDA receptors. Our failure to detect a loss of neurons within the portion of area CA3 sampled from the epileptic hippocampus argues against this latter hypothesis.

The affected hippocampi in 6 of the 7 epileptic patients studied with positron-emission tomography (PET) before surgery were hypometabolic (R. A. Radtke, personal communication). It is possible that the decreased NMDA receptor binding that we measured in these hippocampi had a functional consequence that contributed to the hypometabolism observed. Alternatively, the atrophic segments of these hippocampi may alone be sufficient to explain the hypometabolism observed with PET.

\section{Comparison with other studies}

Interestingly, the increased ASQ receptor binding described here is reminiscent of increased quisqualate-receptor-mediated synaptic responses (Kauer et al., 1988; Muller et al., 1989) and increased quisqualate receptor sensitivity (Davies et al., 1989) that have been found in hippocampal long-term potentiation (LTP), a model of learning and memory. It is possible that similar molecular mechanisms may underlie both LTP and CPE in cases of mesial temporal sclerosis.

However, the alterations in EAA receptor binding in intractable CPE are in sharp contrast to the alterations in receptor binding (Yeh et al., 1989; Okazaki et al., 1989, 1990) and receptor-mediated function (Mody and Heinemann, 1987; Morrisett et al., 1989) identified in the hippocampus of kindled animals. One major difference between the hippocampus of patients with CPE and the hippocampus of kindled rats is that obvious neuronal degeneration is present in CPE but not in kindling. Kindling may be more relevant to human epilepsy cases in which a focal lesion outside of the hippocampus triggers the seizures with minimal or no destruction of hippocampal neurons.

A recent study of EAA receptor binding in the human epileptic hippocampus by Johnston et al. (1989) included some speci- mens with mesial temporal sclerosis and others with tumors but without overt loss of hippocampal neurons. The subgroup with mesial temporal sclerosis exhibited a reduction of NMDA channel binding in subfields of area CA4 (M. Johnston; personal communication), an area not measured in our study but near area $\mathrm{CA} 3$, where we also measured reduced NMDA channel binding. Interestingly, the subgroup with tumors exhibited significantly increased NMDA receptor binding within area CA4 (Johnston et al., 1989). These differences underscore the heterogeneity of medically intractable CPE. They suggest that a given animal model may mimic a subpopulation of epilepsy cascs, but that different stages of the same model or different models will be required to fully understand the diversity of this patient population.

\section{References}

Babb TL, Brown WJ, Pretorius J, Davenport C, Lieb JP, Crandall PH (1984) Temporal lobe volumetric cell densities from temporal lobe cpilepsy. Epilepsia 25:729-740.

Babb TL, Kupfer WR, Pretorius JK, Levesque MF (1989) Light and electron microscopy of mossy fiber terminals in human "epileptic" fascia dentata. Soc Neurosci Abstr 19:236.

Bekkers JM, Stevens CF (1989) NMDA and non-NMDA receptors are co-localized at individual excitatory synapses in cultured rat hippocampus. Nature 341:230-233.

Bonhaus DW, McNamara JO (1988) $N$-methyl-D-aspartate receptor regulation of uncompetitive antagonist binding in rat brain membranes: kinetic analysis. Mol Pharmacol 34:250-255.

Bonhaus DW, Perry WB, McNamara JO (1990) Decreased density of $N$-methyl-D-aspartate, glycine and phencyclidine binding sites in hippocampus of senescent rats. Brain Res, in press.

Collins RC, Tearse RG, Lothman EW (1983) Functional anatomy of limbic seizures: focal discharges from medial entorhinal cortex in rat. Brain Res 280:25-40.

Cotman CW, Monaghan DT (1986) Anatomical organization of excitatory amino acid receptors and their properties. In: Excitatory amino acids and epilepsy (Schwarcz R, Ben-Ari Y, eds), pp 237-352. New York: Plenum.

Croucher MJ, Collins JF, Meldrum BS (1982) Anticonvulsant actions of excitatory amino acid antagonists. Science 216:899-901.

Davies SN, Lester RAJ, Reymann KG, Collingridge GL (1989) Temporally distinct pre- and postsynaptic mechanisms maintain longterm potentiation. Nature 338:500-503.

de Lanerolle NC, Sundareson S, Brines ML, Spencer DD (1989) Phenotypic changes of hippocampal neurons and dynorphin in human epilepsy. Soc Neurosci Abstr 19:340.

Fagg GE, Foster AC, Ganong AH (1986) Excitatory amino acid synaptic mechanisms and neurological function. Trends Pharmacol Sci 7:357-363.

Geddes JW, Chang-Chui H, Cooper SM, Lott IT, Cotman CW (1986) Density and distribution of NMDA receptors in the human hippocampus in Alzheimer's disease. Brain Res 399:156-161.

Glaum SR, Holzwarth JA, Miller RJ (1990) Glutamate receptors activate $\mathrm{Ca}^{+2}$ mobilization and $\mathrm{Ca}^{+2}$ influx into astrocytes. Proc Natl Acad Sci USA 87:3454-3458.

Greenamyre JT, Penny JB, Young AB, D'Amato CJ, Hicks SP, Shoulson I (1985) Alterations in L-glutamate binding in Alzheimer's and Huntington's diseases. Science 227:1496-1498.

Hosford DA, Bonhaus DW, McNamara JO (1988) Radiohistochemical demonstration of NMDA/glycine-activation in rat hippocampus. Eur J Pharmacol 151:501-503.

Hosford DA, Cao Z, Crain BJ, Bonhaus DW, Friedman AH, Nadler JV, McNamara JO (1989a) Excitatory amino acid (EAA) receptor binding in epileptic human hippocampi. Soc Neurosci Abstr 19:1163.

Hosford DA, Crain BJ, Bonhaus DW, Friedman AH, Nadler JV, McNamara JO (1989b) Radiohistochemical demonstration of altered quisqualate and NMDA receptor/channel binding in epileptic human hippocampi. Epilepsia 30:719.

Hosford DA, Bonhaus DW, McNamara JO (1990) A radiohistochemical measure of $\left[{ }^{3} \mathrm{H}\right]-\mathrm{TCP}$ binding to the activated NMDA-receptorgated ion channel in rat brain. Brain Res 516:192-200.

Houser CR, Miyashiro JE, Swartz BE, Walsh GO, Rich JR, DelgadoEscueta AV (1990) Altered patterns of dynorphin immunoreactivity 
suggest mossy fiber reorganization in human hippocampal epilepsy. J Neurosci 10:267-282.

Huettner JE, Bean BP (1988) Block of $N$-methyl-D-aspartate-activated current by the anticonvulsant MK-801: selective binding to open channels. Proc Natl Acad Sci USA 85:1307-1311.

Jansen KLR, Faull RLM, Dragunow M (1989) Excitatory amino acid receptors in human cerebral cortex: autoradiographic distributions of $\left[{ }^{3} \mathrm{H}\right] \mathrm{TCP},\left[{ }^{3} \mathrm{H}\right]$ glycine, L- $\left[{ }^{3} \mathrm{H}\right]$ glutamate, $\left[{ }^{3} \mathrm{H}\right] \mathrm{AMPA}$, and $\left[{ }^{3} \mathrm{H}\right]$ kainic acid binding sites. Soc Neurosci Abstr 19:1164.

Johnston MV, McDonald JW, Hood T, Sackellares C, Garofalo E, McKeever PE, Troncoso J, Gilman S (1989) Elevated NMDA receptor and reduced GABA receptor binding in hippocampus (HIP) from patients with temporal lobe epilepsy (TLE). Soc Neurosci Abstr 19:1215.

Kauer JA, Malenka RC, Nicoll RA (1988) A persistent postsynaptic modification mediates longterm potentiation in the hippocampus. Neuron 1:911-917.

Kloog YR, Haring R, Sokolovsky M (1988) Kinetic characterization of the phencyclidine- $N$-methyl-D-aspartate receptor interaction: evidence for a steric blockade of the channel. Biochemistry 27:843-848.

Konigsmark BW (1969) Methods for the counting of neurons. In: Contemporary research methods in neuroanatomy (Nauta WJH, Ebbesson SOE, eds), pp 315-340. Berlin: Springer.

Lorente de Nó R (1934) The structure of Ammon's horn (Kraft LM, trans). Springfield, MA: Thomas.

Mani RB, Lohr JB, Jeste DV (1986) Hippocampal pyramidal cells and aging in the human: a quantitative study of neuronal loss in sectors CA1 to CA4. Fxp Neurol 94:29-40.

Maragos WF, Penney JB, Young AB (1988) Anatomic correlation of NMDA and ${ }^{3} \mathrm{H}$-TCP-labeled receptors in rat brain. J Neurosci 8:493501 .

Masukawa LM, O'Connor M (1989) Seizure-like neuronal discharges in brain slices of the dentate gyrus from epileptic patients during 1 $\mathrm{Hz}$ stimulation. Soc Neurosci Abstr 19:236.

McGonigle P, Lexow N, Dichter MA, O'Connor MJ (1989) Quantitative autoradiographic determination of the distribution of binding sites for $\left[{ }^{3} \mathrm{H}\right]-\mathrm{MK}-801$ in human hippocampus. Soc Neurosci Abstr 19:1162.

McNamara JO, Russell RD, Rigsbee L, Bonhaus DW (1988) Anticonvulsant and antiepileptogenic actions of MK-801 in the kindling and electroshock models. Neuropharmacology 27:563-568.

Meldrum BS (1985) Possible therapeutic applications of antagonists of excitatory amino acid neurotransmitters. Clin Sci 68:113-122.

Mody I, Heinemann U (1987) $N$-methyl-D-aspartate (NMDA) receptors of dentate gyrus granule cells participate in synaptic transmission following kindling. Nature 326:701-704.
Monaghan DT, Cotman CW (1985) Distribution of $N$-methyl-D-aspartate-sensitive $\mathbf{L}-\left[{ }^{3} \mathrm{H}\right]$-glutamate-binding sites in rat brain. J Neurosci 5:2909-2919.

Monaghan DT, Yao D, Cotman CW (1984) Distribution of $\left[{ }^{3} \mathrm{H}\right]-$ AMPA binding sites in rat brain as determined by quantitative autoradiography. Brain Res 324:160-164.

Morrisett RA, Chow C, Nadler JV, McNamara JO (1989) Biochemical evidence for enhanced sensitivity to $N$-methyl-D-aspartate in the hippocampal formation of kindled rats. Brain Res 496:25-28.

Mouritzen Dam A (1982) Hippocampal neuron loss in epilepsy and after experimental seizures. Acta Neurol Scand 66:601-642.

Muller D, Joly M, Lynch G (1989) Contributions of quisqualate and NMDA receptors to the induction and expression of LTP. Science 242:1699-1702.

Okazaki MM, McNamara JO, Nadler JV (1989) $N$-methyl-D-aspartate receptor autoradiography in rat brain after angular bundle kindling. Brain Res 482:359-364.

Okazaki MM, McNamara JO, Nadler JV (1990) Kainate and quisqualate receptor autoradiography in rat brain after angular bundle kindling. Neuroscience 37:135-142.

Ramón y Cajal S (1968) Studies on the structure of the cerebral cortex. II. Continuation of the study of the ammonic system. J Psychol Neurol 46:113-177.

Represa A, Robain O, Tremblay E, Ben-Ari Y (1989) Hippocampal plasticity in childhood epilepsy. Neurosci Lett 99:351-355.

Reynolds IJ, Murphy SN, Miller RJ (1987) ${ }^{3} \mathrm{H}$-labeled MK801 binding to the excitatory amino acid receptor complex from rat brain is enhanced by glycine. Proc Natl Acad Sci USA 84:7744-7748.

Sutula T, Xiao-Xian H, Cavazos J, Scott G (1988) Synaptic reorganization in the hippocampus induced by abnormal functional activity. Science 239:1147-1150.

Sutula T, Cascino G, Cavazos J, Parada I, Ramirez L (1989) Mossy fiber synaptic reorganization in the epileptic human temporal lobe. Ann Neurol 26:321-330.

Tauck DL, Nadler JV (1985) Evidence of functional mossy fiber sprouting in hippocampal formation of kainic acid-treated rats. $J$ Neurosci 5:1016-22.

Turnbull J (1987) Speculations on disease states induced by excitatory amino acids. Can J Neurol Sci 14:122-126.

Yeh G-C, Bonhaus DW, Nadler JV, McNamara JO (1989) $N$-methyl$\mathrm{D}$-aspartate receptor plasticity in kindling: quantitative and qualitative alterations in the $N$-methyl-D-aspartate receptor-channel complex. Proc Natl Acad Sci USA 86:8157-8160. 